\title{
Seasonal Variations of Physicochemical Characteristics of Brewery Industry Effluent and Receiving Water of Ikpoba-Oha Rivers, Benin City, Nigeria
}

\section{${ }^{1}$ ADEGBITE, SA; ${ }^{2}$ ADELEKE, AE; ${ }^{3 *}$ SANGOREMI, A; ${ }^{1}$ OLADELE, EO}

\author{
${ }^{1}$ Department of Chemical Sciences, Joseph Ayo Babalola University, Ikeji-Arakeji, Nigeria, Email:adexson2003@yahoo.com, ${ }^{4}$ Email: \\ solaoxbee@gmail.com \\ ${ }^{2}$ Department of Basic Sciences, Adeleke University, Ede, Nigeria, Email:adelekeadebayo4christ@ gmail.com \\ ${ }^{3}$ Department of Chemistry, Federal University Otuoke, Bayelsa, Nigeria*Correspondent Author, Email: sangoremiaa@ fuotuoke.edu.ng
}

\begin{abstract}
The impact of the effluents from a Brewery industry on the water quality of Ikpoba-Oha River was carried out during wet and dry seasons, 2016. Water samples from three selected points in the river were analyzed for $\mathrm{pH}$, temperature, total solids, total dissolved solids, Hardness, BOD, COD, DO, Chlorides, phosphates, sulphates. Samples were collected at three points designated as: point 1 (effluent), point 2 (upstream), and point 3 (downstream). The results of the analysis of the effluent obtained on both seasons were: $\mathrm{pH}(5.90-8.38)$, temperature $\left(25.20^{\circ} \mathrm{C}-33.15^{\circ} \mathrm{C}\right)$, chlorides $(12.0-129.2 \mathrm{mg} / \mathrm{l})$, phosphates $(0.9-20.48 \mathrm{mg} / \mathrm{l})$, sulphates $(3.30-53.0 \mathrm{mg} / \mathrm{l})$, nitrates $(3.8-17.20 \mathrm{mg} / \mathrm{l})$, DO $(2.3-$ $4.15 \mathrm{mg} / \mathrm{l})$, Total Hardness $(12.10-425.6 \mathrm{mg} / \mathrm{l})$, Ca hardness $(6.0-296.4 \mathrm{mg} / \mathrm{l})$, Total Solids (44.0-513mg/l), TSS (20$159 \mathrm{mg} / \mathrm{l})$ and TDS $(24-354 \mathrm{mg} / \mathrm{l})$. The levels of most of the parameters monitored are generally higher at the point of effluent discharged into water bodies and dispersed to less malign conditions downstream due to water dilution effect.
\end{abstract}

\section{DOI: https://dx.doi.org/10.4314/jasem.v22i6.3}

Copyright: Copyright (C) 2018 Adegbite et al. This is an open access article distributed under the Creative Commons Attribution License (CCL), which permits unrestricted use, distribution, and reproduction in any medium, provided the original work is properly cited.

Dates: Received: 09 November 2017; Revised: 16 May: 2018; Accepted: 04 June 2018

Keywords: Physicochemical properties, Ikpoba River, Effluent, pH, Hardness.

Most industries around the world are traditionally located in cities for various reasons paramount of which is the ease of discharging their products to consumers. Other reasons include availability of suitable fresh water for their operations and in some cases, sufficient sewer capacities for their effluents. Water is by no doubt one of the most essential needs of human beings for drinking and other purposes (Oyinloye, et al, 2004). In developed countries such as America, Canada and United Kingdom, effluents from industries are discharged into local sewers, usually at low cost, which over the years has been rising steadily in proportion to the level of awareness to protect and balance rather than degrade their environment (Elizabeth, 1999), thus leading to the consideration of "on site" treatment of effluents for industries located in urban areas. However, the situation in developing countries like Nigeria is different. Prior to the incidence of Koko toxic waste in 1988, most industries were discharging their effluents directly into water bodies or public sewers without any form of treatment. There was no evidence of municipal treatment of such wastes; which ultimately ended up in our rivers and streams thus causing massive water pollution (Elizabeth, 2000). The health hazards that have resulted from these pollution incidents include epidemics of cholera, typhoid, hepatitis and other gastro-intestinal disorders which no doubts have caused thousands of deaths.

According to a UNEP/IE/PAC report (1992), water pollution (directly or indirectly) is responsible for 25millions death every year in developing countries (Elizabeth, 2000). Even some of the developed countries were not left out of the ills of environmental pollution. The case of outbreak of mercury poisoning resulting from eating breads made from wheat contaminated with poisoning resulting from eating bread reported in Iraq in 1971 and Cadmium poisoning in Japan known as Itai-Itai (fatal disease) which claimed many lives between 1953-1960 (FEPA, 1991). Thus the Federal Environmental Protection Agency was established in 1988 with a view to regulating the environmental pollution, securing higher standard of living protecting and enhancing the environment both now and future generation. From the foregoing, effluents in Nigeria have to comply with standards or else have their industries closed down indefinitely. Although the emphasis is more on toxic materials, organic materials and solids wastes like those from brewery industries which cause serious concerns to the Federal Government have drastic effect on ecosystem (Aquatic life) the depletion of dissolved oxygen in the rivers. This research work is 
focused in determining the physicochemical properties of effluent from Brewery on Ikpoba-Oha Rivers which acts as a source of drinking water, fishing and irrigation for agricultural purpose to the community.

\section{MATERIALS AND METHODS}

Study Area: This study was carried out in a stretch of the Ikpoba River, a fourth order stream in Benin City, situated within the rainforest belt of Edo State of Southern Nigeria $\left(6.5^{\circ} \mathrm{N}, 5.8^{\circ} \mathrm{E}\right)$. The Ikpoba River rises from Ishan Plateau, flows in a South direction in a sleepy incised valley and through sandy areas of Edo State before passing through Benin City and joining the Ossisomo River. Two major tributaries, Okhuaile River and Erurbi stream join the Ikpoba River. The River in its upper reaches flows through dense rain forest where surface run-off and organic matter derived from surrounding vegetation contributes to allochithonous input. The region consists of secondary rainforest which has been greatly subjected to deforestation and other human activities. The dominant vegetation now comprises rubber palm, bamboo trees and chromolaenaodorataos farming. Although, some fishermen were seen setting traps and gill nets in the study stench. Effluents from brewery are discharged into this river. The three (3) sampling stations (located at the point where brewery effluents is discharged (its upstream and downstream) were selected for this study.

Sample Collection and Preservation: The effluent samples were collected from Brewery Limited located along Benin-Agbor road in Benin City. Received water samples (that is, upstream and downstream) were collected from the Ikpoba river during wet and dry season. The samples were collected and preserved by Ademoroti, (1996); (Aiyesanmi et al., 2006). The physicochemical parameters such as temperature, $\mathrm{pH}$, conductivity, dissolved oxygen (DO), were also determined in situ and site. The samples were kept at $4^{\circ} \mathrm{C}$ prior to analysis of their parameters.

Analysis: All reagents used for analysis are of analytical grades. The temperature of the water samples was determined with the aid of mercury thermometer while the $\mathrm{pH}$ was determined after standardization using $\mathrm{pH}$ meter. Conductivity was measured using conductivity meter. Total Solids (TS), Total Dissolved Solids (TDS) and Total Suspended Solids (TSS) were determined gravimetrically using the evaporating method recommended by Adebisi, (2007). Total hardness (TH) was determined titrimetrically using 0.01MEDTA; Calcium and Magnesium ion in the samples were also determined using EDTA titration. The Dissolved Oxygen (DO) and Biochemical Oxygen demand (BOD) were determined using DO Hanah Kit HI 3810 using Winkler Titration Method.

The Chemical Oxygen Demand (COD) was determined titrimetrically using Standard Iron II Ammonium Sulphate and $0.125 \mathrm{M} \mathrm{K}_{2} \mathrm{Cr}_{2} \mathrm{O}_{7}$.Sulphate was determined colourmetrically using Barium Chloride and reading the absorbance with phosphates determined colourmetrically using $10 \mathrm{ml}$ of VanadoMolybdate reagent and the absorbance was read. The chloride content of these samples was determined by titrating $100 \mathrm{ml}$ of sample agent $0.0257 \mathrm{M} \mathrm{AgNO}_{3}$ using $5 \% \mathrm{~K}_{2} \mathrm{Cr}_{2} \mathrm{O}_{7}$ as indicator. Also, Nitrates concentration was determined spectrometrically using the Standard Method recommended by (Hack, 1985).

\section{RESULTS AND DISCUSSION}

Physicochemical properties of effluent and receiving water samples from a Brewery, Benin City. The temperature of the samples ranges between $\left(28.2^{\circ} \mathrm{C}\right.$ $\left.33.15^{\circ} \mathrm{C}\right)$ and $\left(25.2^{\circ} \mathrm{C}-28.5^{\circ} \mathrm{C}\right)$ for dry and wet season respectively. These ranges are fairly within the recommended safe limit as expressed by FAO $\left(25^{\circ} \mathrm{C}\right.$ $\left.30^{\circ} \mathrm{C}\right)$ and FEPA $\left(40^{\circ} \mathrm{C}\right)$. These values were closed to those obtained by Adeoye, et al., (2013) which recorded a range of $\left(28.94^{\circ} \mathrm{C}-30.20^{\circ} \mathrm{C}\right)$. However, effluents had a higher temperature compared to the upstream which invariably caused an increase temperature of the downstream within the study range. The results obtained during dry season were higher than wet season. This reduction is due to rainfall which leads to regular water flows and hence reduced temperature.

The $\mathrm{pH}$ value ranges between 5.92-8.38 and 5.90-6.5 for dry and wet season. At these seasons, the effluents were slightly acidic and not within the 6-9 $\mathrm{pH}$ range of FEPA (1991) but close to the value recorded by (Okafor, 2001) for effects of effluent on Ikpoba River in Benin City. This may be due to acidic contents of the industrial effluents and Dissolved Carbon Dioxide from the atmosphere. Generally, there was a reduction in $\mathrm{pH}$ during the wet season than for the dry season and this may be due to dilution of water which leads to regular water flows. Total Solids (TS) values obtained for the samples $(44-513 \mathrm{mg} / \mathrm{l})$ obtained for all samples here below the recommended value of $2000 m g / l$ by FEPA. The observed values for Total Suspended Solid (TSS) in all the samples analyzed at dry season were below $30 \mathrm{mg} / \mathrm{l}$ limits recommended by FEPA while those recorded during wet season were below 500mg/l recommended by WHO (1993). Similarly, the observed values for Total Dissolved Solid (TDS) in all the samples were below $2000 \mathrm{mg} / \mathrm{l}$ limits recommended by FEPA. However, all the values recorded for the water samples during wet 
season were higher compared to dry season. The results showed that Total Hardness ranges between $(12.10-20.50 \mathrm{mg} / \mathrm{l})$ and $(49.85-425 \mathrm{mg} / \mathrm{l})$ for dry and wet seasons respectively. These values were below or within the range of $500 \mathrm{mg} / \mathrm{l}$ recommended by W.H.O (1993). Generally, the results were higher than values recorded by Okafor (2001). Finding suggested that total hardness was higher during wet season than dry season. However, the calcium $(6.0-10.5 \mathrm{mg} / \mathrm{l})$ and magnesium hardness $(2.10-10.52 \mathrm{mg} / \mathrm{l})$ obtained for both seasons were significantly below FEPA and WHO recommended values of $180 \mathrm{mgk}$ and $500 \mathrm{mg} / \mathrm{l}$ respectively. It was also observed that the results for downstream $(16.52 \mathrm{mg} / \mathrm{l})$ were higher than that of the upstream $(12.10 \mathrm{mg} / \mathrm{l})$ dry season and $(59.10 \mathrm{mg} / \mathrm{l})$ $49.85 \mathrm{oC}$ ) for wet season which showed the impact of effluent from industry.

The Dissolved Oxygen (DO) obtained for both seasons fall within the recommended safe limit as expressed by FEPA and WHO; that is, it showed a good compliance with both FEAP and WHO standard values of $20 \mathrm{mg} / \mathrm{l}$ and $5 \mathrm{mg} / \mathrm{l}$ respectively. The result for the wet season is slightly lowered than dry season. This may be due to inflow of large amount of rainfall during raining season or temperature change since the dissolved oxygen decreases with increase in temperature. However, the results were lower compared to finding by Okafor (2001). This establishes the degree of freshness of a river (Fakayode, 2005).

Biochemical Oxygen Demand ranges between 19.2$250 \mathrm{mg} / \mathrm{l}$ and $21.9-290 \mathrm{mg} / \mathrm{l}$. The highest BOD value was obtained for effluent at wet season which invariably caused an increase in BOD values of the downstream. The values for upstream were below the recommended standard 30mg/l by FEPA, 1991 and Okafor, 2001 for Ikpoba River. However, the values were lower compared to the $1250 \mathrm{mg} / \mathrm{l}$ published by FEPA, 1988 for Guinness Nigeria Plc and Adebisi, 2007 for Nigeria Brewery Plc., Ibadan. The results obtained for upstream for both seasons were within WHO value of $(<50 \mathrm{mg} / \mathrm{l})$ while downstream value were far above the level to show the impact of effluent on the river.

Table 1: The Physicochemical Properties Of Effluent And Receiving Water During Dry And Wet Seasons From A Brewery Industry On Ikpoba-Oha River, Benin City

\begin{tabular}{|c|c|c|c|c|c|c|c|c|c|c|c|c|c|c|}
\hline & $\begin{array}{l}\text { Temp } \\
\text { (c) }\end{array}$ & $\mathrm{pH}$ & $\begin{array}{l}\text { Genjes } \\
\text { tixity } \\
(\mu \mathrm{s} / \mathrm{cm})\end{array}$ & $\begin{array}{l}\mathrm{BOD} \\
\text { (mell) }\end{array}$ & $\begin{array}{l}\mathrm{COD} \\
(\mathrm{mgL})\end{array}$ & $\begin{array}{l}\text { Chloride } \\
\mathrm{s}(\mathrm{cl})\end{array}$ & $\begin{array}{l}\text { Disal. } \\
\text { Oxygen }\end{array}$ & $\begin{array}{l}\text { Sulphat } \\
\text { \&s }\end{array}$ & Phos. & Nitrates & $\begin{array}{l}\text { Total } \\
\text { Solids } \\
\text { (TS) }\end{array}$ & $\begin{array}{l}\text { Total } \\
\text { Soan } \\
\text { Solid } \\
\text { (TSS) }\end{array}$ & $\begin{array}{l}\text { Total } \\
\text { Dissol } \\
\text { Soild } \\
\text { (TDS) }\end{array}$ & $\begin{array}{l}\text { Total } \\
\text { Hard- } \\
\text { neas }\end{array}$ \\
\hline \multicolumn{15}{|l|}{ Dry Season } \\
\hline Effluent & $\begin{array}{l}33.15 \\
\pm 1.05\end{array}$ & $\begin{array}{l}5.92 \pm \\
0.00\end{array}$ & $\begin{array}{l}420.00 \\
\pm 0.00\end{array}$ & $\begin{array}{l}250.00 \\
\pm 0.10\end{array}$ & $\begin{array}{l}1100.0 \\
0 \neq 0.5\end{array}$ & $\begin{array}{l}12.00= \\
0.25\end{array}$ & $\begin{array}{l}2.20 \pm \\
0.50\end{array}$ & $\begin{array}{l}11.25= \\
2.75\end{array}$ & $\begin{array}{l}6.55 \pm \\
3.05\end{array}$ & $\begin{array}{l}3.80 \pm \\
0.02\end{array}$ & $\begin{array}{l}130.00 \\
\pm 0.25\end{array}$ & $\begin{array}{l}26.00= \\
4.00\end{array}$ & $\begin{array}{l}104.00 \\
\pm 1.50\end{array}$ & $\begin{array}{l}20.50 \\
\pm 0.30\end{array}$ \\
\hline Upstream & $\begin{array}{r}28.20 \\
\pm 0.20 \\
\end{array}$ & $\begin{array}{l}8.38 \pm \\
0.00\end{array}$ & $\begin{array}{l}50.00= \\
0.50\end{array}$ & $\begin{array}{l}19.20= \\
0.02\end{array}$ & $\begin{array}{l}110.00 \\
\pm 0.30\end{array}$ & $\begin{array}{l}18.90= \\
0.06\end{array}$ & $\begin{array}{l}4.15 \pm \\
0.15\end{array}$ & $\begin{array}{l}8.50 \pm \\
1.50\end{array}$ & $\begin{array}{l}0.90 \pm \\
0.30\end{array}$ & $\begin{array}{l}6.40 \pm \\
0.01\end{array}$ & $\begin{array}{l}44.00= \\
0.12\end{array}$ & $\begin{array}{l}20.00= \\
0.00\end{array}$ & $\begin{array}{l}24.00= \\
0.35\end{array}$ & $\begin{array}{l}12.10 \\
\pm 0.15\end{array}$ \\
\hline Downstream & $\begin{array}{r}31.50 \\
\pm 0.30\end{array}$ & $\begin{array}{l}6.73 \pm \\
0.00\end{array}$ & $\begin{array}{l}60.00= \\
0.50\end{array}$ & $\begin{array}{l}120.00 \\
\pm 0.05\end{array}$ & $\begin{array}{l}148.00 \\
\pm 0.50 \\
\end{array}$ & $\begin{array}{l}34.60= \\
1.00\end{array}$ & $\begin{array}{l}3.24 \pm \\
0.12 \\
\end{array}$ & $\begin{array}{l}3.00 \pm \\
1.50\end{array}$ & $\begin{array}{l}1.00 \pm \\
0.30\end{array}$ & $\begin{array}{l}8.20 \pm \\
0.01\end{array}$ & $\begin{array}{l}80.00= \\
0.15\end{array}$ & $\begin{array}{l}25.00= \\
0.05\end{array}$ & $\begin{array}{l}55.00= \\
0.05\end{array}$ & $\begin{array}{l}16.25 \\
\pm 0.25\end{array}$ \\
\hline Wet Season & & & & & & & & & & & & & & \\
\hline Effluent & $\begin{array}{r}28.50 \\
\pm 0.10 \\
\end{array}$ & $\begin{array}{l}5.90 \pm \\
0.00\end{array}$ & $\begin{array}{l}950.00 \\
\pm 0.50\end{array}$ & $\begin{array}{l}290.00 \\
\pm 0.50\end{array}$ & $\begin{array}{l}1500 \pm 1 \\
.00\end{array}$ & $\begin{array}{l}129.20 \pm \\
0.10\end{array}$ & $\begin{array}{l}215 \pm \\
0.10\end{array}$ & $\begin{array}{l}53.00= \\
1.00\end{array}$ & $\begin{array}{l}20.48 \\
\pm \\
0.10\end{array}$ & $\begin{array}{l}6.45 \pm \\
0.02\end{array}$ & $\begin{array}{l}513.00 \\
\pm 0.10\end{array}$ & $\begin{array}{l}159.30 \\
\pm 1.50\end{array}$ & $\begin{array}{l}354.00 \\
\pm 2.50\end{array}$ & $\begin{array}{l}425.6 \\
0 \pm 0.0 \\
5\end{array}$ \\
\hline Upstream & $\begin{array}{l}25.20 \\
\pm 0.20\end{array}$ & $\begin{array}{l}6.50 \pm \\
0.00\end{array}$ & $\begin{array}{l}512.95 \\
\pm 0.25\end{array}$ & $\begin{array}{l}21.90= \\
0.02\end{array}$ & $\begin{array}{l}223.00 \\
\pm 0.03\end{array}$ & $\begin{array}{l}39.55= \\
0.06\end{array}$ & $\begin{array}{l}3.10 \pm \\
0.15\end{array}$ & $\begin{array}{l}19.05= \\
0.15\end{array}$ & $\begin{array}{l}13.95 \\
\pm \\
0.15\end{array}$ & $\begin{array}{l}13.80= \\
0.01\end{array}$ & $\begin{array}{l}484.90 \\
\pm 0.40\end{array}$ & $\begin{array}{l}132.05 \\
\pm 0.15\end{array}$ & $\begin{array}{l}352.85 \\
\pm 0.25\end{array}$ & $\begin{array}{l}49.85 \\
\pm 0.20 \\
\end{array}$ \\
\hline Downstream & $\begin{array}{r}27.00 \\
\pm 0.30\end{array}$ & $\begin{array}{l}6.10 \pm \\
0.00\end{array}$ & $\begin{array}{l}526.45 \\
\pm 0.15\end{array}$ & $\begin{array}{l}125.00 \\
\pm 0.15\end{array}$ & $\begin{array}{l}278.00 \\
\pm 0.50\end{array}$ & $\begin{array}{l}58.90=1 \\
00\end{array}$ & $\begin{array}{l}2.30 \pm 0 . \\
12\end{array}$ & $\begin{array}{l}24.20= \\
0.10\end{array}$ & $\begin{array}{l}18.95 \\
\pm \\
0.35\end{array}$ & $\begin{array}{l}17.20= \\
0.01\end{array}$ & $\begin{array}{l}478.35 \\
\pm 0.15\end{array}$ & $\begin{array}{l}140.50 \\
\pm 0.20\end{array}$ & $\begin{array}{l}337.85 \\
\pm 0.35\end{array}$ & $\begin{array}{l}59.10 \\
\pm 0.20\end{array}$ \\
\hline
\end{tabular}

The Chemical Oxygen Demand (COD) values obtained from this industry were significantly higher than FEPA (1991) and WHO (1984) recommended values of $40 \mathrm{mg} / \mathrm{l}$ and $50 \mathrm{mg} / \mathrm{l}$ respectively. The high values obtained might suggest that high amount of the product was lost to the stream. High COD in water also indicates the presence of biologically organic substances (Sawyer et al, 1978). Values obtained at wet season were generally higher than that of dry season due to dilution of samples at wet season since there may be inflow of water armed with debris and other organic matter into the river during this period.

The chloride content of the samples ranged from $(12.0-129.2 \mathrm{mg} / \mathrm{l})$. It showed that all values obtained were below WHO (1993) 250mg/l and FEPA (1991) $600 \mathrm{mg} / \mathrm{l}$ permissible limit for drinking water and effluent discharge respectively. These values were fairly similar to those reported by Okafor (2005) on Ikpoba River during dry season. Seasoned variation was higher for the wet season than for dry season. This high chloride concentration during wet season may be due to domestic sewage pollution. Concentration of other anions were: phosphate for dry and wet season $(0.9-6.55 \mathrm{mg} / \mathrm{l})$ and $13.95-20.4 \mathrm{mg} / \mathrm{l}$; Sulphates (3.30$11.25 \mathrm{mg} / \mathrm{l})$ for dry and $(19.05-53.0 \mathrm{mg} / \mathrm{l})$ for wet season. Nitrates $(3.80-8.20 \mathrm{mg} / \mathrm{l})$ during dry season and from $(6.45-17.20 \mathrm{mg} / \mathrm{l})$ at wet season. However, the results for upstream values were lowered compared to downstream which showed the concentrations of their anions were elevated in the river due to the effluent discharge. The values for nitrates and sulphates were lower than the recommended values for FEPA and WHO, 20mg/l and 
$50 \mathrm{mg} / \mathrm{l}$ respectively for (Nitrates) and $500 \mathrm{mg} / \mathrm{l}$ and $50 \mathrm{mg} / \mathrm{l}$ for sulphates. However, the results for phosphates were below WHO (1984) limits $0.4 \mathrm{mgk}$ but below FEPA (1991) limit of $29 m g / l$ and values reported by Amoo et al., 2005.

Conclusion: The result of the water quality measurement showed that all parameters determined were within the WHO permissible limit except phosphate, total solid, total suspended solid, BOD and COD. These effluents have negative impact on the river because of its high organic and bacterial content and also due to anthropogenic activities. Thus, if industrial activities are not properly controlled and modified, it may lead to serious environmental pollution and degradation of Ikpoba-Oha River in the nearest future.

\section{REFERENCES}

Adebisi, SA (2007). Effect of effluents from selected industries on water and plants in Ibadan metropolis. $\mathrm{PhD}$ Thesis, Federal University of Technology, Akure.

Ademoroti, CMA (1996). Standard Methods for Water and Analysis. $1^{\text {st }}$ Edition, Foludex Press Limited, Ibadan, Nigeria. pg 111-119.

Aiyesanmi, AF; Ipinmoroti, KO; Adeeyinwo, CE (2006). Baseline Water Quality Status of Rivers within Okitipupa, Southeast Belt of the Bituminous Sands Field of Nigeria. J. Sci. 40, 6271.
Amoo, IA; Ajayi, OO; Amuda, OS (2004). Performance Optimization of some Chemical Coagulants in the treatment of wastewater from food industries Sci. Focus (28).

APHA (1998). Standard Methods for the Examination of Water and Waste Water WEF and AWWA, $20^{\text {th }}$ Edition, United States of America.

Fakayode, SO (2005). Impact Assessment of Industrial Effluent on River Quality of the receiving Alaro River in Ibadan, Nigeria. AJEEMRAGEE 10:1-3.

FEPA (1991). Guidelines and Standards for Environmental Pollution Control in Nigeria. Federal Environmental Protection Agency. Pg 197

Food and Agiculture Organization, FAO (1983): Guidelines for Water Quality." A reference manual, Rome, Italy. Pg. 60.

Oyinloye, A; Jegede, GO (2004). Geophysical Survey, Geochemical and Microbiological Investigation of Ground and Well water in Ado-Ekiti, North East, South Western, and Nigeria. Global J. Geologic. Sci. 2(2): 234-242. 